\title{
Organic Matter Processing in Tropical Streams
}

\author{
Karl M. Wantzen, Catherine M. Yule, Jude M. Mathooko, \\ and Catherine M. Pringle
}

I. Introduction 44

II. Organic Matter Dynamics 44

III. The Significance of Physical and Chemical Composition of Leaves 54

IV. Microbial Contributions to Organic Matter Processing 55

V. The Role of Shredders in Organic Matter Processing 56

VI. Methodological Constraints on Decomposition Studies 57

VII. Autochthonous Plant Litter 58

VIII. Conclusions 58

References 60

Organic matter derived from many sources provides a basis for stream food webs. In terms of weight, leaves from the surrounding land constitute the largest allochthonous source of energy for stream consumers, but other items, including fruits, flowers, wood and twigs, and terrestrial insects, are also important. Timing of allochthonous inputs can vary markedly due to the phenology of the riparian vegetation, retention mechanisms in the aquatic-terrestrial transition zone, and local climate (especially the incidence of high-rainfall events), but seasonality of litter inputs is different, and often much less marked, than is typical of streams in temperate latitudes. As in such streams, litter decomposition rates depend on the interaction of physical factors (flow, temperature), water chemistry (dissolved nutrients), and biological agents (micro-organisms and detritivores - especially shredding invertebrates). Because vascular plant biodiversity in the tropics is high, varied leaf characteristics (hardness, phenolic content, and other aspects of leaf chemistry) contribute to great variability in breakdown rate: fast-decomposing leaves persist for a few days only, whereas highly recalcitrant species take well over a year to decompose. In all the above cases, the decomposition process includes an initial rapid leaching phase when water-soluble compounds are lost, followed by colonization by micro-organisms (fungi and bacteria), and subsequent mechanical breakdown of the leaf structure by invertebrate shredder and hydraulic forces. Undecomposed leaves are sometimes exported downstream during flood events, and thence deposited in water-logged riparian zones or, in some cases, forming dense accumulations of peat that are important as carbon sinks and as habitat for specialized biota. Recent research indicates that the role of invertebrate shredders in processing organic matter in tropical streams is less than in temperate latitudes, and there may be a higher proportion of material that is recalcitrant and/or exported from streams (or stored as peat) before it is decomposed completely. Autochthonous energy sources may be particularly important to consumers in tropical streams, and there is some evidence of a lesser reliance on allochthonous organic matter than in temperate streams. 


\section{INTRODUCTION}

Decomposition is a central process in the organic matter budgets of stream ecosystems (Kaushik and Hynes, 1971; Webster and Benfield, 1986; Boulton and Boon, 1991; Abelho, 2001). The terms 'decomposition' and 'organic matter processing' are rather general terms that refer to the metabolism of a wide range of organic substances (dead plant and animal material) through an assortment of processes that include a variety of physical, chemical, and biological players. In addition, metabolic processes resulting in decomposition occur at different sites within stream ecosystems: for example, in pools of the riparian zone, on floodplains, within debris dams, and on or among the sediments in riffles and streams. Any comparison between latitudes, habitats, or types of organic substances can be confounded by a multiplicity of environmental variables and site characteristics, and generalizations must be made with caution. Here, we synthesize information on decomposition in tropical streams and make some comparisons with temperate systems. We focus mainly on particulate organic matter (POM).

\section{ORGANIC MATTER DYNAMICS}

\section{A. Diversity of Particulate Organic Material}

The most intensively studied source of organic matter in streams is plant litter - especially senescent leaves and dead wood - that has been shed from terrestrial and riparian plants. Other allochthonous energy sources include flowers, fruits and seeds, pollen, carcasses, and feces from terrestrial organisms but are much less apparent, and generally less studied, due to their relatively low biomass, local occurrence or high temporal variability. Nonetheless, their contribution to in-stream food webs can be significant due to a relatively high energy and/or nutrient contents compared to leaves and wood. Significantly, the types of organic matter that are most conspicuous in streams are precisely those that have not yet been consumed, degraded or processed by biota - either because these entered the water only recently, or because they are recalcitrant (i.e. resistant to decomposition). This may give rise to a false impression of the relative importance of different energy sources to stream consumers. For instance, fruits, pollen, and fleshy petals (e.g. of bat-pollinated flowers) are nutritious and eaten readily by terrestrial consumers; and because of these characteristics, they can be expected to decompose quickly in streams. Conversely, leaves, bark, and wood have been selected to resist terrestrial herbivores and forces of degradation while they are on the living plant, and nutrients may be translocated from leaves during senescence. For these reasons, such plant litter decomposes slowly in streams.

Allochthonous organic inputs derived from animals include the rain of honeydew from aphids or feces and frass produced by herbivores in the riparian zone. Large numbers of terrestrial insects fall into streams and, depending on the structure of the surrounding vegetation and thus the magnitude of this 'rain', stream drift may contain considerable amounts of terrestrial insects that can enhance food availability for fishes and other predators (Mathooko and Mavuti, 1992; Chan and Dudgeon, 2006). A manipulative study in a temperate Japanese stream showed a cascading effect whereby fish predation pressure on aquatic insects increased considerably when terrestrial insects falling from the canopy were excluded (Nakano et al., 1999).

In some cases, tropical streams flow underneath bird or bat colonies and feces and animal carcasses can considerably raise the organic matter inputs. Although direct studies are lacking, analogous human impacts provide an idea of their probable effects. Thus, in an extremely nutrient-poor erosion gully in Mato Grosso, Brazil, dead chickens dumped from a nearby farm caused a 10-fold increase in benthic invertebrate densities on artificial substrates (Wantzen and Junk, 2006; Fig. 1). The importance of fruits in the diet of fishes has been well documented in 


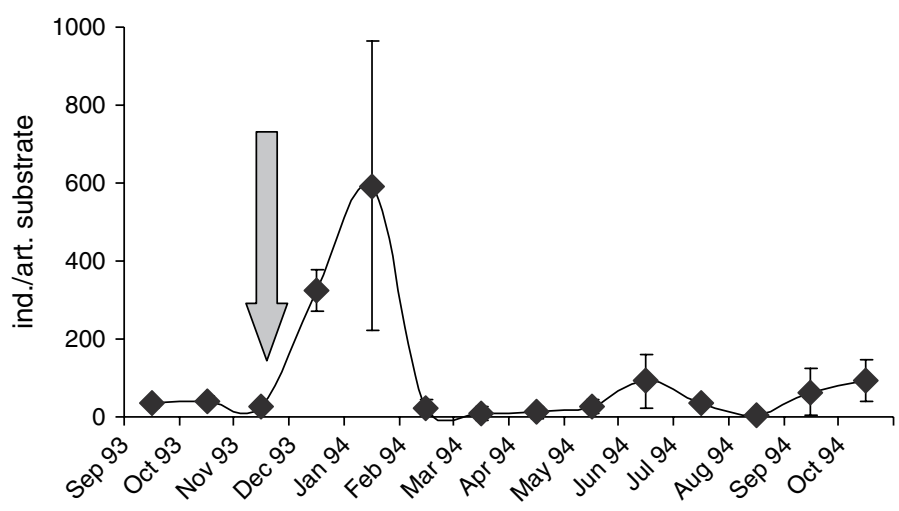

FIGURE 1 Effects of artificial increase of food sources for benthic insect larvae in an erosion-gully stream 'Formoso' in Mato Grosso, Brazil. Dumping of dead chickens from a chicken farm (about 200-week-old chicken bodies, black arrow) into the small rivulet (discharge: $20 \mathrm{~L} \mathrm{~s}^{-1}$ ) increased the abundance of aquatic insects colonizing artificial substrates by a factor of 10-100 within 10 weeks. When the corpses were fully consumed, insect densities declined to the levels similar to those prevailing before dumping. Modified after Wantzen and Junk (2006).

Amazonian rainforest streams (Knöppel, 1970; Goulding et al., 1988) and elsewhere (Dudgeon, 1999), and Larned (2000) and Larned et al. (2001) have drawn attention to their potential importance as a food source for stream invertebrates. Estimates of the magnitude of such inputs are scarce, but fruits contributed about $45 \mathrm{~g}$ ash-free dry weight (AFDW) $\mathrm{m}^{-2} \mathrm{yr}^{-1}$ to the total litter fall into a closed-canopy site on the Njoro River, Kenya (Magana, 2000), and riparian fruit input to tropical streams is sometimes high and continuous (Larned et al., 2001). The importance of these and other nutrient- and energy-rich allochthonous inputs for fish and invertebrates in tropical streams has probably been underestimated (Wantzen and Junk, 2000; Larned et al., 2001).

The largest proportion of allochthonous organic matter entering most streams comprises leaves, bark, and wood - especially twigs. The variety of these inputs depends on the biodiversity of the riparian ecosystem, which is the source of most of this organic matter. Since vascular plant biodiversity increases with decreasing latitude (Barthlott et al., 1996), there are substantial regional differences in the composition of litter entering streams. Riparian vegetation in temperate latitudes is often species poor, and in Central Europe, for example, generally no more than 10 tree species contribute to the bulk of the litter input in a particular stream. Few species shed bark or twigs in a regular manner, or produce energy-rich flowers or fruit parts. In tropical latitudes, diversity is higher, e.g. gallery forests in Brazilian Cerrado streams have about 50 species of trees per hectare (Wantzen, 2003). Such diversity is typical; rainforests in Costa Rica's Caribbean lowlands support more than 320 tree species (Hartshorn, 1983) and about 1000 species occur on the whitewater floodplain of the Amazon (Wittmann et al., 2004). In the Old-World topics, dipterocarp forests in lowland Borneo have an estimated 3000 tree species (IUCN, 1991), at densities more than 100 tree species per hectare (Kiew, 1998), whereas 186 species were recorded along a rift valley stream in the highlands of Kenya (Mathooko and Kariuki, 2000). The implications of this diversity for carbon processing in streams are yet unclear, and their link between riparian plant community composition and energy flow or in-stream food webs needs has to be investigated.

Given the diversity of potential allochthonous energy sources in tropical streams, analyses of carbon budgets should not only include studies of the decomposition pattern of leaves from important or dominant species, but also assessment of other POM sources and their dynamics. This will involve a variety of samplers (e.g. drift nets for POM $>200 \mu \mathrm{m}$; water-filled pan traps for falling insects; litter traps of various designs as in, for example, Fig. 2). Since tropical 


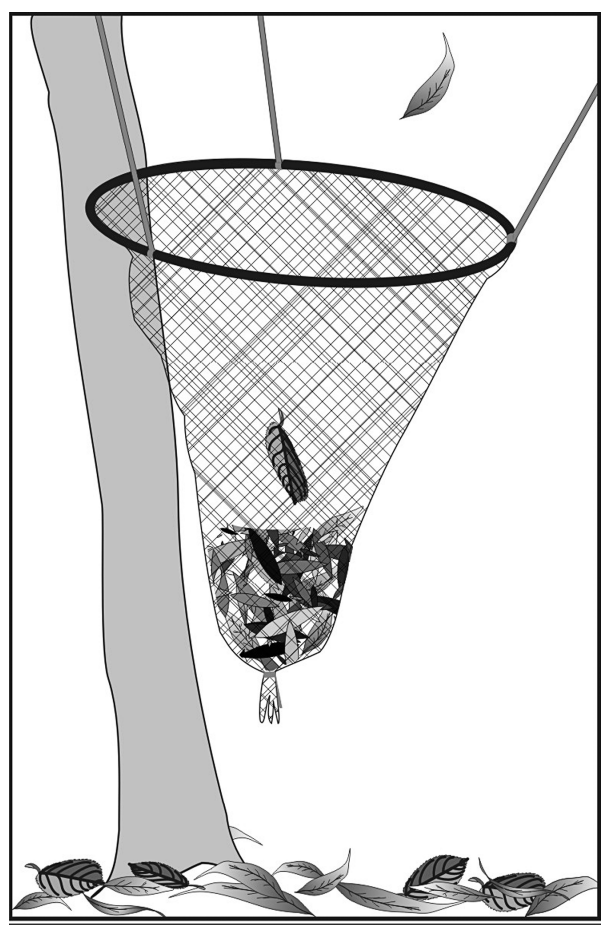

FIGURE 2 Standard leaf trap for measurement of litter inputs (diameter: $60 \mathrm{~cm}$ ). Construction is simple, using flexible plastic canes and mosquito mesh.

latitudes differ in seasonality from the temperate zone, which will have implications for the timing of allochthonous inputs into streams, due consideration must be given to sampling effort in order to account for and adequately document temporal and spatial variations in inputs. Estimate of the larger wood fractions require long-term studies and a larger sampling area that may involve marking whole trees on standardized plots. There is certainly no 'one-size-fitsall' sampling strategy for tropical regions, as quantities and types (or quality) of litter inputs vary strongly between sites and years. In the lowland dipterocarp forests of Southeast Asia, for instance, the simultaneous massive flowering and mast fruiting of dozens of tree species occurs at irregular, multiyear intervals, across thousands of kilometres (Janzen, 1974; Sakai, 2002). The affects of this phenomenon are to create a 'hot moment' for stream energy budgets (Wantzen and Junk, 2006), and may have important consequences for consumers who are able to respond quickly to the increased availability of allochthonous sources. Given the occurrence of such marked interannual variation, some of the published literature on litter inputs to tropical streams, and particularly data accumulated over a year or less (such as most of those summarized in Tables I and II), may need to be treated as rather conservative or indicative of the lower end of the scale of temporal variability.

\section{B. Timing of Litter Inputs}

In north temperate vegetation is mainly made up of either evergreen coniferous forests or deciduous broad-leaf forests that shed leaves when day length and temperature decrease in autumn each year (e.g. Dudgeon and Bretschko, 1996). The timing of leaf loss in tropical riparian forests is more variable (Fig. 3), in part because they contain a broad range of deciduous 
TABLE I Annual Input of Different Litter Types and their Carbon to Nitrogen Ratios at Open- and Closed-Canopy Sites along the Nyoro River, Kenya [Data from Magana (2000)]

\begin{tabular}{llcr}
\hline Litter type & \multicolumn{1}{c}{ Site } & $\mathrm{kg} \mathrm{m}^{-2} \mathrm{yr}^{-1}$ & $C: N$ \\
\hline Wood and bark & Open canopy & 0.036 & 51.9 \\
\multirow{2}{*}{ Fruits } & Closed canopy & 0.271 & 39.9 \\
& Open canopy & 0.061 & \\
FPOM & Closed canopy & 0.045 & 19.4 \\
\multirow{2}{*}{ Unidentified fragments } & Open canopy & 0.014 & 58.1 \\
& Closed canopy & 0.143 & 0.196 \\
\hline
\end{tabular}

TABLE II Summary of Data on Litter Fall $\left(\mathrm{kg} \mathrm{m}^{-2} \mathrm{yr}^{-1}\right)$ at a Range of Tropical Sites

\begin{tabular}{|c|c|c|c|c|c|c|}
\hline Forest type & Location & Total litter & Leaf litter & $\% N$ & $\% p$ & Source \\
\hline $\begin{array}{l}\text { Montane } \\
\quad(2550 \mathrm{~m} \text { asl })\end{array}$ & Amazonia & 0.70 & 0.46 & 1.2 & 0.09 & Veneklaas $(1991)^{\dagger}$ \\
\hline $\begin{array}{l}\text { Montane } \\
\quad(3370 \mathrm{~m} \text { asl })\end{array}$ & Amazonia & 0.43 & 0.28 & 0.7 & 0.04 & Veneklaas $(1991)^{\dagger}$ \\
\hline Upland & Amazonia & 0.80 & & 1.3 & 0.04 & Dantas and Phillipson (1989) \\
\hline Terra firme & Amazonia & 0.74 & 0.56 & 1.4 & 0.03 & Klinge and Rodrigues $(1968)^{\dagger}$ \\
\hline Terra firme & Amazonia & 0.79 & 0.64 & - & - & Franken $(1979)^{\dagger}$ \\
\hline Terra firme & Amazonia & 0.83 & 0.54 & $1.8 *$ & $0.02 *$ & Luizao $(1989)^{\dagger}$ \\
\hline Terra firme & Amazonia & 1.02 & 0.76 & $1.6 *$ & $0.03 *$ & Cuevas and Medina $(1986)^{\dagger}$ \\
\hline Riparian & Amazonia & 0.64 & 0.43 & 1.2 & 0.02 & Franken $(1979)^{\dagger}$ \\
\hline Terra firme & Amazonia & 0.74 & 0.47 & $1.4 *$ & $0.03 *$ & Luizao $(1989)^{\dagger}$ \\
\hline Campina & Amazonia & - & - & 1.0 & 0.05 & Klinge $(1985)^{\dagger}$ \\
\hline Tall caatinga & Amazonia & $\overline{0} .56$ & $\overline{0} .40$ & 0.7 & 0.05 & Cuevas and Medina $(1986)^{\dagger}$ \\
\hline Bana & Amazonia & 0.24 & 0.21 & 0.6 & 0.02 & Cuevas and Medina $(1986)^{\dagger}$ \\
\hline Igapó & Amazonia & 0.68 & 0.53 & - & - & Adis et al. $(1979)^{\dagger}$ \\
\hline Igapó & Amazonia & 0.67 & - & 1.4 & - & Irmler $(1982)^{\dagger}$ \\
\hline Average & Amazonia & 0.68 & $\overline{0} .48$ & 1.2 & 0.04 & McClain and Richey $(1996)^{\dagger}$ \\
\hline Gallery forest & $\begin{array}{l}\text { Cerrado, } \\
\quad \text { Central Brazil }\end{array}$ & 0.82 & & & & Wantzen and Wagner (2006) \\
\hline $\begin{array}{l}\text { Evergreen } \\
\text { savanna }\end{array}$ & $\begin{array}{l}\text { Pantanal, } \\
\quad \text { Central Brazil }\end{array}$ & $0.75-1.02$ & & & & Haase (1999) \\
\hline $\begin{array}{l}\text { Semi-deciduous } \\
\text { savanna }\end{array}$ & $\begin{array}{l}\text { Pantanal, } \\
\quad \text { Central Brazil }\end{array}$ & $0.48-0.75$ & & & & Haase (1999) \\
\hline $\begin{array}{l}\text { Tropical } \\
\text { rainforest }\end{array}$ & Pasoh, Malaysia & 1.06 & $0.63-0.75$ & & & Ogawa (1978) \\
\hline $\begin{array}{l}\text { Shorea } \\
\text { plantation }\end{array}$ & India & & 0.59 & & & Puri $(1953)^{\ddagger}$ \\
\hline $\begin{array}{l}\text { Tectona } \\
\text { plantation }\end{array}$ & India & & 0.53 & & & Seth et al. $(1963)^{\ddagger}$ \\
\hline $\begin{array}{l}\text { Deciduous } \\
\text { forest }\end{array}$ & Sagar, India & & $0.26-0.93$ & & & Upadhyaya $(1955)^{\ddagger}$ \\
\hline $\begin{array}{l}\text { Deciduous } \\
\text { forest }\end{array}$ & Varansi, India & & $0.10-0.62$ & & & Singh $(1968)^{\ddagger}$ \\
\hline $\begin{array}{l}\text { Deciduous } \\
\text { forest }\end{array}$ & Udaipur, India & & 0.4 & & & Garg and Vyas $(1975)^{\ddagger}$ \\
\hline Average & $10^{\circ} \mathrm{S}-10^{\circ} \mathrm{N}$ & 0.68 & & & & Bray and Gorham (1964) \\
\hline
\end{tabular}

*Calculated as percent of leaf litter.

${ }^{\dagger}$ Cited from McClain and Richey (1996).

${ }^{\ddagger}$ Cited from Garg and Vyas (1975). 
Temperate Zone

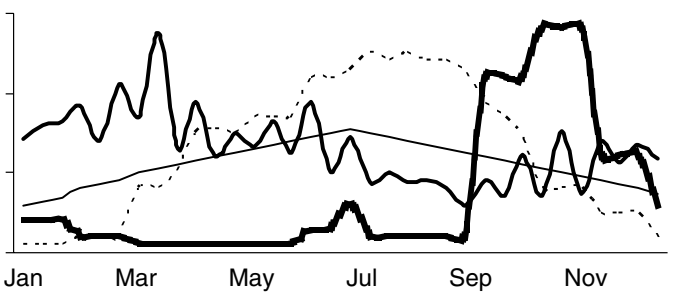

Seasonal Tropics

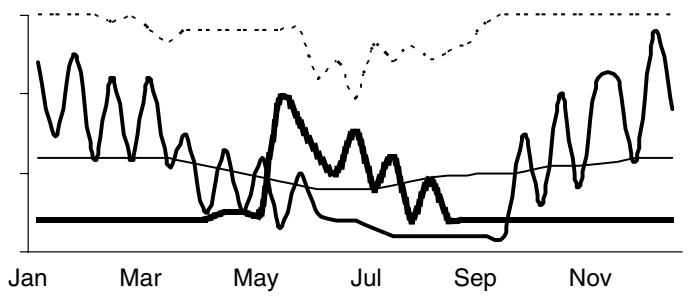

Aseasonal Tropics

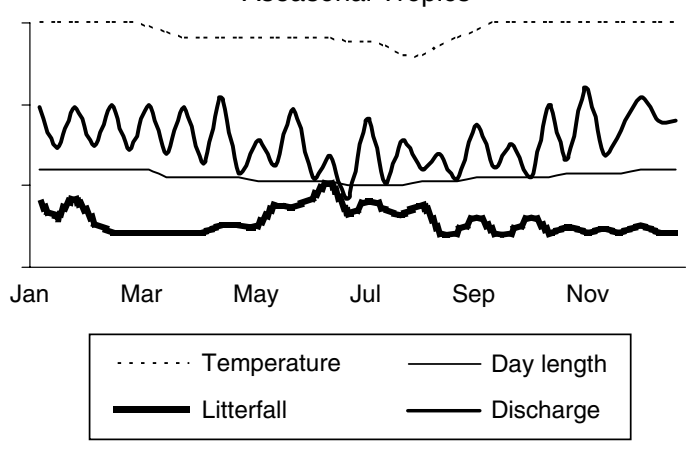

FIGURE 3 Idealization of seasonal changes in temperature, day length, discharge, and timing of leaf litter input in temperate and tropical latitudes.

to semi-deciduous tree species that occur in highly mixed associations. Even when seasonal leaf fall does occur, it may not occur as synchronously as in the temperate latitudes, and may reflect a response to water scarcity (or other factors) rather than temperature and day length. In some parts of the tropics, the constant supply of water in the vicinity of streams and rivers provides conditions for tree growth that may change the timing of litter fall relative to that in more upland or drier sites (Wantzen and Junk, in press). For example, gallery forests along streams running through seasonal savannas (e.g. the Brazilian Cerrado, or the African Andropogon savannas) appear as permanently green belts compared to the much more seasonal vegetation further away. In wetter, less-seasonal tropical regions, the riparian tree phenology follows more or less closely the patterns of the surrounding vegetation and the appearance of the whole community (e.g. in tropical rainforests) is evergreen even if leaf fall is actually occurring all year round.

Contrary to most temperate species, the lifespan of some tropical tree leaves can extend over several years (Coley, 1988). Others lose their leaves on a seasonal basis or more erratically during the year. Because of the variety of species-specific patterns, distinct seasonal trends in allochthonous inputs to streams are lacking, especially in equatorial latitudes (e.g. Yule and Pearson, 1996). In more seasonal parts of the tropics, especially toward the northern and southern limits, triggers for phenological events like flowering, leaf flushing, and fruiting, or shedding leaves and bark, include monsoonal rainfall and drought (Dudgeon and Bretschko, 1996), floodplain inundation (Worbes et al., 1992), and fire (Oliveira-Filho et al., 1989). Moreover, torrential rainstorms, typhoons, and cyclones, as well as human activities such as fruit harvesting, contribute large amounts of fresh green leaves and wood to streams. All of these factors combine to make the predictability of timing and magnitude of leaf fall in the tropics considerably less pronounced than in most parts of the temperate zone. 


\section{Accession Pathways}

Litter input is composed of variable proportions of shed leaves falling directly into the stream channel, and lateral transport of fallen leaves that are blown or flushed into the channel. Lateral transport depends on the bank steepness, soil surface heterogeneity, understorey vegetation, wind and surface runoff, as well as human modification of the riparian vegetation, and may be at least half of that falling into the stream directly (Dudgeon, 1992) depending on the type and stature of riparian vegetation. In temperate zones, synchronous shedding of tree leaves in autumn combined with die-back of riparian herbs and strengthening winds enhance the transport of dry litter into the streams during snow-free periods in winter (Wantzen and Wagner, 2006). Litter accession into tropical streams is reduced by plants, which act like a mechanical filter to retain leaves and retard lateral transport. Retention of fallen litter by rapidly growing basidiomycetous fungi and moss has been reported on forested upland slopes in Puerto Rico (Covich, 1988) and in Kenya (Mathooko et al., 2001), and basidiomycetes reduce downhill leaf transport rates to Puerto Rican streams by $~ 40 \%$ (Lodge and Asbury, 1988). These fungi contribute to the maintenance of litter mats that retard soil erosion, and tree roots as well as associated mycorrhizae tend to retain the intact leaves with the result that they break down in situ and 'tighten' nutrient cycles. This can be seen from a study of streams in Cerrado of Mato Grosso, Brazil, where deployment of leaf traps two distances $(1 \mathrm{~m}$ and $30 \mathrm{~m})$ from the channel indicated negligible horizontal transport perpendicular to the stream channel at sites that did not flood seasonally (K. M. Wantzen, unpublished observations).

Topical rainstorms transport large quantities of litter into and along streams and rivers. They flush the floodplain and surrounding hillslopes bringing in leaves and wood that may already have been subject to some decomposition. Short intensive flow pulses may also flush out litter accumulations from deep pools and carry them downstream or deposit them in the riparian zone. In streams with very 'flashy' hydrographs, litter may be alternately picked up and deposited in terrestrial, aquatic, or marshy environments where it may be subject to differing decomposition processes.

\section{Decomposition and Storage of Organic Matter in Riparian Zones}

Wetting and drying has an important influence on litter decomposition and the distribution of in-stream and riparian POM, especially in the large areas of the tropics where streams experience alternation of distinct dry and wet seasons or monsoon cycles. As rains and runoff fluctuate seasonally, the wetted area of the stream channel expands or contracts. Consequently, two zones can be identified: first, a wet zone defined as 'the sediment area wetted by water flow at the time of observation' and, second, a dry zone defined as 'the dry area on both sides of a stream bordered by the edge of the flowing water at the time of observation and the highest extent reached by the stream flow in its history' (Mathooko, 1995). Decomposition of Dombeya goetzenii (Sterculiaceae) leaves was four times faster in the wet zone than in the dry zone in the Njoro River, Kenya (Mathooko et al., 2000a; see also Table III). Similar results have been reported from Australia (Boulton, 1991) and Amazonia (Furch and Junk, 1997), and an experimental study in which litter was moved from the dry to the wet zone confirmed this effect (Table III). Transport of leaves from dry riparian sites into the wetted stream channel appears to promote nutrient release and fragmentation. Boulton (1991) demonstrated that microbial enrichment (measured as ATP) of submerged leaves was higher than that of leaves that were exposed to air, and enhancement of microbial activity certainly contributes significantly to increased decomposition of submerged litter. Small streamside pools or fringing wetlands in riparian regions of swamp forests can serve as important sites or 'hotspots' of decomposition (Wantzen and Junk, 2000; see also Chapter 7), but only as long as there is connectivity between 
TABLE III Comparison of the Processing Rates ( $-k$ per day) of Leaves of Dombeya goetzenii in a Wet-Dry Interchange Experiment (Data from Mathooko et al., 2000a)

\begin{tabular}{lc}
\hline Treatment of the litterbags & $-k$ \\
\hline Litterbags in dry zone & 0.171 \\
Litter bags interchanged from dry to wet zone & 0.711 \\
Litter bags in wet zone & 0.789 \\
Litter bags interchanged from wet to dry zone & 0.004 \\
\hline
\end{tabular}

the lateral water body and the stream channel. Isolated floodplain and wetland pools may serve as traps for organic matter (Wantzen et al., 2005a).

In some instances, the riparian zone is so retentive for organic matter that the export of coarse material to streams seems to be virtually non-existent. Much of the organic material in the Malaysian, Indonesian, and Papua New Guinea streams is broken down to fine particulate matter prior to entering the streams (C. M. Yule, personal observation; Yule and Pearson, 1996). Generally, the only intact leaves are those that fall directly from the canopy overhead. In Konaiano Creek on Bougainville Island, Papua New Guinea, the mean standing stock of detritus was 0.04 to $0.23 \mathrm{~kg} \mathrm{~m}^{-2}$ (Yule, 1996), whereas in North American streams at a similar altitude stocks ranged from 0.2 to $0.9 \mathrm{~kg} \mathrm{~m}^{-2}$ (Cummins et al., 1989); see Dudgeon and Bretschko (1996) for the European-Asian comparison. While these values are not exceptionally low, most of the detritus in Konaiano Creek comprised sticks and twigs as well as fine organic material rather than intact leaves or leaf parts (Yule and Pearson, 1996).

\section{E. In-stream Decomposition Processes}

Decomposition of organic matter in streams is caused by a number of interacting processes (Fig. 4), and their joint effects are usually studied by measuring loss of detrital mass over time. This is not wholly satisfactory, since weight loss [or changes in ash-free dry weight (AFDW)]

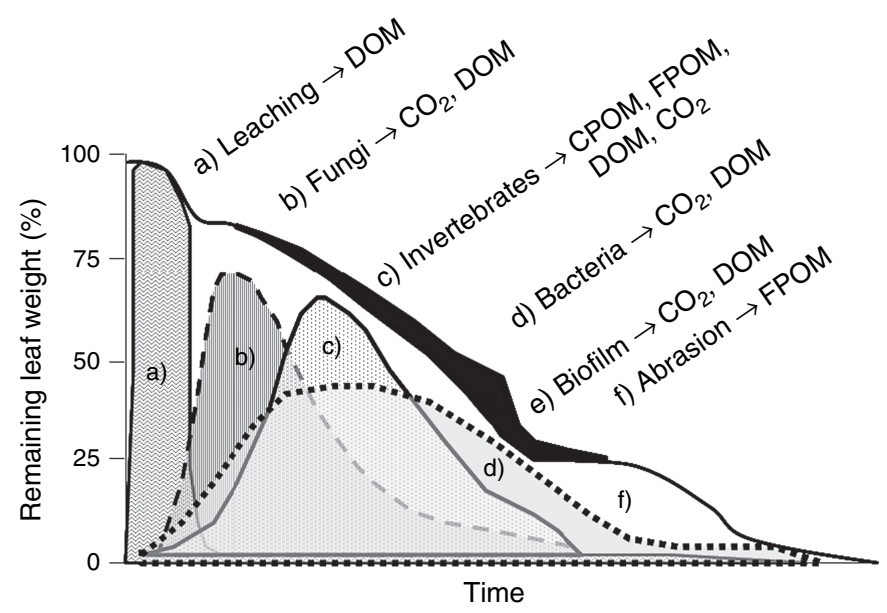

FIGURE 4 Synthesis of processes acting during decomposition of plant litter in fresh water and their effects on weight loss. Note that a temporary increase of litter dry weight may be caused by growth of biofilms on the leaf surface (e). The relative contribution of individual processes (a)-(f) may differ between streams. Highly modified after Suberkropp (1998). 
does not provide direct information on the fate of this material or its uptake and assimilation by consumers. Gessner et al. (1999) propose a more organism-centered perspective on leaf-litter breakdown, which acknowledges that 'degradation' may begin even before leaves are shed. In tropical rainforests, many living leaves are colonized by epiphyllic algae and mosses. The surface characteristics and the chemistry of these leaves are also influenced by colonization of fungi and activity of herbivores. While parts of individual leaves may be killed when infected by pathogenic fungi, some fungi appear to maintain leaf activity in order to profit by the products of photosynthesis even after the onset of senescence of infected leaves (Butin, 1995). All these processes interfere with the quality of the leaves before they are shed and eventually reach the water. The term 'leaching' describes the extraction of soluble compounds by water. Leaching rates are affected by the integrity of the leaf surface, and leaching may occur during rain when senescing leaves are still attached to the tree. Once fallen leaves enter the stream, osmotic breakage of dead cell walls, penetration by fungal hyphae, and softening of the structural elements by microbial enzymes combined with feeding by invertebrate shredders enhance leaching. Leaching rates generally peak $24-48 \mathrm{~h}$ after immersion (Fig. 4) but some leaching continues for weeks (France et al., 1997). The leachates (sugars, amino acids, etc.) are generally energy-rich and easily absorbed by bacteria (Strauss and Lamberti, 2002). Studies in temperate waters have shown that benthic decomposition of leaves enhanced microalgal biomass in the water column, demonstrating the role of allochthonous detritus as a nutrient source for primary production (Fazi and Rossi, 2000). The importance of epilithic algae growing on submerged litter in tropical streams has not been studied, but they could provide a significant enrichment of the food value of leaves consumed by invertebrates. As Fig. 4 shows, a temporary increase of dry weight during decomposition may be caused by the growth of biofilms on the leaf surface (as well as increased endophytic microbial biomass), as has been reported for Syzygium cordatum (Myrtaceae) litter by Mathooko et al. (2000b). Laboratory studies show that light favors biofilm quality on litter and thus the growth of temperate-zone invertebrate shredders (Franken et al., 2005), and there is no reason to assume that this effect does not occur in tropical streams.

Fungi and bacteria growing on the leaf surface and inside the mesophyll produce enzymes that degrade structural polysaccharides, such as cellulose, resulting in a softening of leaf structure and an increase in food value for shredders (Kaushik and Hynes, 1971). Fungal biomass and reproduction generally peaks 1 or 2 weeks after immersion in temperate streams (Gessner and Chauvet, 1994). A few existing studies on tropical streams confirm this pattern (e.g. 10-20 days in Columbia; Mathuriau and Chauvet, 2002), or indicate that it may occur even more quickly (e.g. within 7 days in Costa Rica; Stallcup et al., 2006). Invertebrate shredders and large benthic omnivores (decapods, crabs, and fish) contribute to the comminution and consumption of the litter and associated microbes (see Section V) and, together with physical degradation by the water current, reduce the leaf particles to tiny fragments and fibres. Although the retention of coarse litter in some tropical headwaters appears generally high (Mathooko, 1995; Morara et al., 2003), large amounts of leaf material and fine fragments of organic material are transported to the lower course and floodplains especially, as described earlier, during spates and high-flow events. This organic material forms large accumulations in the deposition zone of rivers, often alternatively layered as sandy-loamy layers within 'sand/debris dunes' (Fittkau, 1982; Wantzen et al., 2005).

\section{F. Abiotic Factors Affecting In-stream Decomposition}

The influence of submergence and wetting on decomposition has been described earlier (see Section D) but processing of allochthonous detritus in streams can be affected by other aspects of stream hydrology. Foremost among these is retentiveness, which determines where 
decomposition of allochthonous organic material actually takes place once it has entered the stream. Roots, fallen branches, and stones act as obstacles that retain drifting litter (e.g. Mathooko et al., 2001; Morara et al., 2003), and coarse gravel riffles are especially efficient retainers of organic matter (Hynes, 1970). While the form and extent of stony retention structures depend on the geological setting, the amount of wood in the stream reflects the species composition, stature, and condition of the riparian forest. Forest streams in undisturbed catchments contain large amounts of logs and have heterogeneous channels that contribute to efficient litter retention and may allow formation of debris dams. On the other hand, stream and river management and flow regulation (or channelization) is often accompanied by wood removal (Diez et al., 2000), and aggressive forestry practices or vegetation clearance may alter wood inputs and can cause bank erosion leading ultimately to reduced retention capacity (Wantzen, 2003; 2006). Where streams suffer from siltation, increased shear stress favors physical disintegration of the leaf structure, rather than processing of litter by microbes and invertebrates.

In seasonal tropical streams, strong rainstorm events at the onset of the wet season flush out much of the litter that might have accumulated during lower-flow periods (Franken, 1979; Pearson et al., 1989). Frequent recurrence of spates of flood events may 'reset' the system (sensu Fisher, 1983) and carry away leaves before degradation can occur. In such cases, large quantities of leaves may be transported out of smaller tropical streams (Mathooko et al., 2001; Morara et al., 2003) or decomposed in the wetlands and along floodplains of larger rivers (Wantzen and Junk, 2000). For example, some southern temperate streams New Zealand have natural 'flashy' flow regimes and hence tend to have low retention capacity for leaves. Rounick and Winterbourn (1983) have suggested that low retentiveness was the cause of scarcity of specialised invertebrate shredders in such systems, and that much litter breakdown (fragmentation) was probably accomplished by physical processes. A similar pattern of high leaf export has been observed by Schwarz and Schwoerbel (1997) in Mediterranean streams on Corsica, and may be anticipated in tropical streams (especially those with steep courses) that experience high rainfall.

Sediment transport during spates may bury leaf litter. Studies in temperate streams indicate that buried leaves decomposed more slowly than those on the surface of the stream bed (Metzler and Smock, 1990), and were subject to less feeding by invertebrates although they did not differ in protein content (Herbst, 1980). By contrast, Mayack et al. (1989) reported increased breakdown of buried leaves due to feeding by tipulid (Diptera) larvae. Observations from Neotropical streams and rivers suggest that burial of leaves by sediment layers reduces decomposition and may lead to accumulation of layers of organic matter in floodplain sand dunes (Wantzen et al., 2005b; Rueda-Delgado et al., 2006).

While spates transport litter from streams, water scarcity or lack of flow also negatively affects decomposition. In seasonal eucalypt forest streams in Australia, periods of flow cessation during the dry season result in the accumulation of leaves, because plant leachates, high temperatures, and reduced oxygen are inimical to the activities of detritivorous invertebrates (Bunn, 1988). In floodplain areas, where elevated flows in the river mainstem cause backflooding of tributary streams, reduced flows in tributaries result in litter accumulations with characteristic faunal assemblages (e.g. Henderson and Walker, 1986). Substantial reductions in rates of leaf decomposition occurred during the backflooding phase in an Amazonian floodplain tributary, although dissolved oxygen was still present (Rueda-Delgado et al., 2006; see also Table IV). In deep or isolated water bodies on floodplains, there may be sufficient microbial activity associated with litter accumulations to deplete dissolved oxygen levels entirely; this and associated hydrogen sulphide production commonly causes mass mortality of aquatic invertebrates during the inundation phase (Junk and Robertson, 1997) with consequential declines in metazoan-mediated litter processing. 
TABLE IV Summary of the Results of Recent Studies of the Processing Rates ( $-k$ per day) of Tree Leaves in Tropical Streams

\begin{tabular}{|c|c|c|c|c|c|}
\hline Tree species & Location & Method & $\begin{array}{l}\text { Duration } \\
\text { (days) }\end{array}$ & $-k$ & Source \\
\hline $\begin{array}{l}\text { Vangueria } \\
\quad \text { madagascariensis }\end{array}$ & Njoro River, Kenya & Wire cages & 70 & 0.047 & $\begin{array}{l}\text { Dobson et al. } \\
\text { (2003) }\end{array}$ \\
\hline Dombeya goetzenii & Njoro River, Kenya & Wire cages & 70 & 0.010 & $\begin{array}{l}\text { Dobson et al. } \\
\text { (2003) }\end{array}$ \\
\hline Dombeya goetzenii & Njoro River, Kenya & Litter bag & 70 & $\begin{array}{l}0.711- \\
0.789\end{array}$ & $\begin{array}{l}\text { Mathooko et al. } \\
\text { (2000a) }\end{array}$ \\
\hline Syzygium cordatum & Njoro River, Kenya & Wire cages & 70 & 0.022 & $\begin{array}{l}\text { Dobson et al. } \\
\text { (2003) }\end{array}$ \\
\hline Syzygium cordatum & Njoro River, Kenya & Litter bag & 56 & 0.001 & $\begin{array}{l}\text { Mathooko et al. } \\
\text { (2000b) }\end{array}$ \\
\hline Rhus natalensis & Njoro River, Kenya & Wire cages & 70 & 0.026 & $\begin{array}{l}\text { Dobson et al. } \\
\text { (2003) }\end{array}$ \\
\hline Cecropia latiloba & $\begin{array}{c}\text { Arenosa FDP, } \\
\text { Colombia }\end{array}$ & Litter bag & 56 & 0.031 & $\begin{array}{l}\text { Rueda-Delgado } \\
\text { et al. }(2006)\end{array}$ \\
\hline Cecropia latiloba & $\begin{array}{c}\text { Arenosa BFP, } \\
\text { Colombia }\end{array}$ & Litterbag & 56 & 0.009 & $\begin{array}{l}\text { Rueda-Delgado } \\
\text { et al. }(2006)\end{array}$ \\
\hline Tessaria integrifolia & $\begin{array}{c}\text { Arenosa FDP, } \\
\text { Colombia }\end{array}$ & Litter bag & 56 & 0.029 & $\begin{array}{l}\text { Rueda-Delgado } \\
\text { et al. }(2006)\end{array}$ \\
\hline Tessaria integrifolia & $\begin{array}{c}\text { Arenosa BFP, } \\
\text { Colombia }\end{array}$ & Litter bag & 56 & 0.009 & $\begin{array}{l}\text { Rueda-Delgado } \\
\text { et al. }(2006)\end{array}$ \\
\hline Symmeria paniculata & $\begin{array}{c}\text { Arenosa FDP, } \\
\text { Colombia }\end{array}$ & Litter bag & 56 & 0.010 & $\begin{array}{l}\text { Rueda-Delgado } \\
\text { et al. }(2006)\end{array}$ \\
\hline Symmeria paniculata & $\begin{array}{c}\text { Arenosa BFP, } \\
\text { Colombia }\end{array}$ & Litter bag & 56 & 0.001 & $\begin{array}{l}\text { Rueda-Delgado } \\
\text { et al. }(2006)\end{array}$ \\
\hline Salix humboldtiana & Paraná, Argentina & Litter bag & 56 & 0.0119 & $\begin{array}{l}\text { Capello et al. } \\
\text { (2004) }\end{array}$ \\
\hline Croton gossypifolius & Cabuyal, Colombia & Litter bag & 43 & 0.0651 & $\begin{array}{l}\text { Mathuriau and } \\
\text { Chauvet (2002) }\end{array}$ \\
\hline Clidemia sp. & Cabuyal, Colombia & Litter bag & 43 & 0.0235 & $\begin{array}{l}\text { Mathuriau and } \\
\text { Chauvet (2002) }\end{array}$ \\
\hline Cecropia schreberiana & $\begin{array}{l}\text { Puerto Rico } \\
\text { (micro-organisms } \\
\text { excluded) }\end{array}$ & $\begin{array}{l}\text { Laboratory } \\
\text { microcosms }\end{array}$ & 84 & 0.00083 & $\begin{array}{l}\text { Wright and Covich } \\
(2005)\end{array}$ \\
\hline Cecropia schreberiana & $\begin{array}{l}\text { Puerto Rico } \\
\text { (micro-organisms } \\
\text { present) }\end{array}$ & $\begin{array}{l}\text { Laboratory } \\
\text { microcosms }\end{array}$ & 84 & 0.0035 & $\begin{array}{l}\text { Wright and Covich } \\
(2005)\end{array}$ \\
\hline Dacryodes excelsa & $\begin{array}{l}\text { Puerto Rico } \\
\text { (micro-organisms } \\
\text { excluded) }\end{array}$ & $\begin{array}{l}\text { Laboratory } \\
\text { microcosms }\end{array}$ & 84 & 0.0014 & $\begin{array}{l}\text { Wright and Covich } \\
(2005)\end{array}$ \\
\hline Dacryodes excelsa & $\begin{array}{l}\text { Puerto Rico } \\
\text { (micro-organisms } \\
\text { present) }\end{array}$ & $\begin{array}{l}\text { Laboratory } \\
\text { microcosms }\end{array}$ & 84 & 0.0073 & $\begin{array}{l}\text { Wright and Covich } \\
(2005)\end{array}$ \\
\hline Trema integerrima & $\begin{array}{l}\text { La Selva Biological } \\
\text { Station, Costa } \\
\text { Rica }\end{array}$ & Litter bag & 21 & 0.0451 & Ardón et al. (2006) \\
\hline Castilla elastica & $\begin{array}{l}\text { La Selva Biological } \\
\text { Station, Costa } \\
\text { Rica }\end{array}$ & Litter bag & 80 & 0.0064 & Ardón et al. (2006) \\
\hline
\end{tabular}


TABLE IV (continued)

\begin{tabular}{|c|c|c|c|c|c|}
\hline Tree species & Location & Method & $\begin{array}{l}\text { Duration } \\
\text { (days) }\end{array}$ & $-k$ & Source \\
\hline Zygia longifolia & $\begin{array}{l}\text { La Selva Biological } \\
\text { Station, Costa } \\
\text { Rica }\end{array}$ & Litter bag & 80 & 0.0020 & Ardón et al. (2006) \\
\hline $\begin{array}{l}\text { Radermachera } \\
\text { glandulosa }\end{array}$ & $\begin{array}{l}\text { Second-order } \\
\text { streams, Thailand }\end{array}$ & Leaf packs & 35 & 0.0413 & $\begin{array}{l}\text { Parnrong et al. } \\
\text { (2002) }\end{array}$ \\
\hline Pometia pinnata & $\begin{array}{l}\text { Second-order } \\
\text { streams, Thailand }\end{array}$ & Leaf packs & 35 & 0.0236 & $\begin{array}{l}\text { Parnrong et al. } \\
\text { (2002) }\end{array}$ \\
\hline Hevea brasiliensis & $\begin{array}{l}\text { Second-order } \\
\text { streams, Thailand }\end{array}$ & Leaf packs & 35 & 0.0636 & $\begin{array}{l}\text { Parnrong et al. } \\
(2002)\end{array}$ \\
\hline Nephelium lappaceum & $\begin{array}{l}\text { Second-order } \\
\text { streams, Thailand }\end{array}$ & Leaf packs & 35 & 0.0380 & $\begin{array}{l}\text { Parnrong et al. } \\
\text { (2002) }\end{array}$ \\
\hline $\begin{array}{l}\text { Eucalyptus } \\
\text { camaldulensis }\end{array}$ & $\begin{array}{l}\text { Second-order } \\
\text { streams, Thailand }\end{array}$ & Leaf packs & 35 & 0.0747 & $\begin{array}{l}\text { Parnrong et al. } \\
\text { (2002) }\end{array}$ \\
\hline Acacia mangium & $\begin{array}{l}\text { Second-order } \\
\text { streams, Thailand }\end{array}$ & Leaf packs & 35 & 0.0682 & $\begin{array}{l}\text { Parnrong et al. } \\
\text { (2002) }\end{array}$ \\
\hline
\end{tabular}

\section{THE SIGNIFICANCE OF PHYSICAL AND CHEMICAL COMPOSITION OF LEAVES}

High vascular plant biodiversity in the tropics has prompted suggestions that leaf quality (especially phytochemistry) has a more important influence on decomposition dynamics than in the case of temperate streams (e.g. Stout, 1989; Irons et al., 1994; Aerts, 1997). Leaf chemical properties known to affect litter decomposition in aquatic ecosystems include tannins and other phenolics (Stout, 1989; Ostrofsky, 1997; Wantzen et al., 2002), lignin (Gessner and Chauvet, 1994), nitrogen content (e.g. Melillo et al., 1983), and carbon-to-nitrogen or carbon-to-phosphorus ratios (Enríquez et al., 1993). Leaves have evolved not only to optimize photosynthesis but also to be defended against terrestrial herbivores, especially insects, and there is evidence that the amounts of defensive compounds that they contain increase with leaf age (Coley, 1988). Chemicals remaining in fallen leaves, especially proanthocyanidins, may retard decomposition by inhibiting activities of microbes and invertebrates (Wantzen et al., 2002). Acid waters (typically pH 3.5-3.7), low dissolved oxygen, and tough leaves high in tannins and lignin retard the decomposition of litter in Malaysian peat swamps where even fruits and flowers do not break down readily (Fig. 5; C. M. Yule, unpublished observations); in such situations, partly decomposed litter can build up layers of peat up to $20 \mathrm{~m}$ thick. Leaf recalcitrance is a key contributor to this build up, as species of leaves that lack defensive compounds break down quite rapidly in the peat swamp. There are no invertebrate shredders, and the peat-swamp food web seems to be based on bacteria that utilize dissolved organic matter leached from leaves and other detritus (C. M. Yule et al., unpublished observations). Elsewhere, leachates from litter may have rather different effects; for instance, soluble polyphenols from eucalypt leaves inhibit microbial activity during low-flow conditions in Australian streams (Bunn, 1988), and several periods of inundation and leaching appear necessary before microbes can fully utilize eucalypt leaves in intermittent streams (Boulton and Boon, 1991). Likewise, Walker (1986, 1995) has shown that leachates from leaves in Amazonian blackwaters inhibit bacterial growth and, in turn, influence the occurrence of mosquitoes (whose larvae feed on planktonic bacteria) in Amazonian blackwater and whitewater areas.

In addition to potential 'antifeedant' compounds such as polyphenols and tannins (for a discussion of terminology, see Duffey and Stout, 1996), structural compounds (i.e. lignin and 


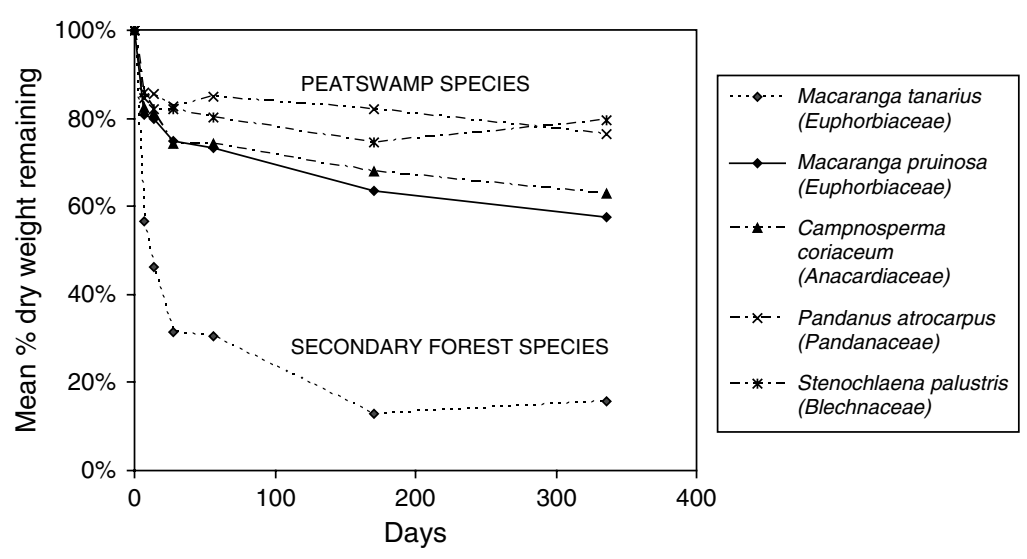

FIGURE 5 Breakdown of leaves within litter bags in a Malaysian peat swamp over a year. Leaves of peat-swamp trees hardly decomposed, but leaves of a secondary forest species broke down relatively rapidly (C. M. Yule and L. Gomez, unpublished observations).

cellulose) tend to be higher in tropical leaves than in their temperate counterparts (Coley and Barone, 1996). They remain in the leaf matrix until the end of the decomposition process that and, therefore, have longer lasting effects than other defensive compounds are leached relatively quickly. Indeed, Gessner and Chauvet (1994) considered that lignin played a key role in controlling hyphomycete fungal growth on litter. In lowland Costa Rican streams, it appears that the lignin and cellulose content of litter limit the extent of phosphorus stimulation of leaf breakdown, fungal biomass, and microbial respiration (Ardón et al., 2006).

\section{MICROBIAL CONTRIBUTIONS TO ORGANIC MATTER PROCESSING}

The interplay and relative importance of microbes that contribute to the decomposition of organic matter streams is poorly understood, especially so in the tropics (Wright and Covich, 2005). Studies in temperate streams indicate that there is a functional overlap among different groups (e.g. Webster and Benfield, 1986; Graça, 1993; Gessner and Chauvet, 1994; Gessner et al., 1997; Raviraja et al., 1998). For instance, aquatic hyphomycetes perform well at low water temperatures (Bärlocher and Kendrick, 1974) and dominate fungal assemblages in temperate streams (Gessner et al., 1997), but they may lose their 'advantage' over other fungal taxa in warmer waters (Graça, 1993). In a seminal paper, Irons et al. (1994) hypothesized that the rate of microbially mediated processing of leaf litter will rise with decreasing latitude, i.e. that the role of microbes will be relatively more important in the tropics than in the temperate zone. Given that decomposition rates tend to increase with temperature, as does microbial metabolism, there is certainly a biological basis for this hypothesis, but the activity of other consumers might rise with temperature also, and it is not clear how microbial assemblage composition or functional organization might change with latitude. There is a large body of taxonomic information on aquatic hyphomycetes in tropical streams (e.g. Marvanova, 1997), but insufficient data to draw any robust conclusions about the relative contribution of hyphomycetes, other fungi and bacteria to litter decomposition in the tropics or to generalize about changes in their representation as decomposition proceeds. The results of the existing literature are inconclusive; for instance, litter breakdown rate did not change between streams with high and low hyphomycete diversity and productivity (Raviraja et al., 1998). In Western Australian streams, actinomycete bacteria seem to contribute more than that of hyphomycetes 
to decomposition of Eucalyptus obliqua (Bunn, 1988). While dense growths of fungal hyphae have been reported on submerged litter in Central Amazonia (Henderson and Walker, 1986), the presence of fungal biomass may not necessarily be correlated with high levels of growth or metabolic activity (Gessner and Chauvet, 1994). Chemical exclosure experiments in Puerto Rico indicated that bacteria and fungi perform different functions in litter processing since selective poisoning of either one or both groups indicated the presence of non-additive effects (Wright and Covich, 2005). A particularly interesting study by Rueda-Delgado et al. (2006) in a Columbian floodplain stream showed that although fungal hyphae were scarce on decomposing litter, leaf ergosterol content (a biomarker of fungal biomass) was comparable to that reported from litter in European streams (e.g. Mathuriau and Chauvet, 2002). In lowland Costa Rican streams, high hyphomycete fungal biomass (measured as ergosterol) on leaves in lowland Costa Rican streams was associated with fast breakdown rate of high-quality leaves (Rosemond et al., 2002, Ardón et al., 2006), but the leaf characteristics and the high ambient levels of phosphorus in these streams limit our ability to generalize from these results. Clearly more data are needed, particularly on the role of bacteria in the latter stages of leaf breakdown when the substrate is highly fragmented. Improvement of techniques to estimate bulk microbial biomass is also needed, and must take account of the fact that ergosterol does not occur in all fungi.

\section{THE ROLE OF SHREDDERS IN ORGANIC MATTER PROCESSING}

There are many reports of a paucity or a conspicuous lack of shredders in tropical streams in Africa, Asia, and the Neotropics systems (e.g. Walker, 1987; Dudgeon, 1992, 1994, 1999, 2000; Irons et al., 1994; Dudgeon and Bretschko, 1996; Yule, 1996; Rosemond et al., 1998; Dudgeon and Wu, 1999; Dobson et al., 2002; Mathuriau and Chauvet, 2002; Rueda-Delgado et al., 2006; Wantzen and Wagner, 2006). Far fewer researchers record either similar shredder representation as in north temperate streams (in tropical Queensland, Australia: Cheshire et al., 2005 ) or even high litter breakdown rates due to the presence of crabs acting as macro-shredders (Moss, 2007). Elsewhere in the tropics, there is anecdotal information of leaf-processing proceeded by microbial activity in the virtual absence of invertebrate shredding (e.g. in Malaysian peat swamps; C. M. Yule, unpublished observations). The body of evidence from the tropics, thus far, is that the importance of invertebrate shredders for the comminution of allochthonous inputs and facilitation of fine-particle-feeding detritivores (filters and gatherer-collectors), and their dominance or co-dominance of headstream benthic communities, does not coincide with the models of community structure and function embodied in the River Continuum Concept (Vannote et al., 1980). Finally, this concept to tropical streams and rivers must be reconsidered (e.g. Wantzen and Wagner, 2006), and its applicability to temperate running waters has also been questioned (e.g. Heard and Richardson, 1995; Schwarz and Schwoerbel, 1997) but especially so in the tropics. Certainly, the concept needs to be adjusted to take account of tropical peat swamps, and organic matter dynamics on floodplains (see Chapter 7 of this volume).

There is evidence that omnivorous fishes and decapod crustaceans play key roles in detrital processing in some tropical streams (Wootton and Oemke, 1992; Irons et al., 1994; Crowl et al., 2001; March et al., 2001). Fishes that feed on allochthonous material are much more common in tropical than in temperate streams (e.g. Bowen, 1983; Wootton and Oemke, 1992; Dudgeon, 1999). Island streams can be dominated by omnivorous decapod shrimps which play a key role in organic matter processing and mobilization (Covich and McDowell, 1996; Pringle et al., 1999; Crowl et al., 2001; Larned et al. 2001; March et al., 2001; Souza and Moulton, 2005). These omnivores are generally larger than insect shredders and rapidly process considerable volumes of coarse and fine organic matter. Rates of detrital processing varied as 
a function of the nature of the shrimp assemblage along an elevational gradient in a Puerto Rican stream (March et al., 2001); fastest rates were found at high-elevation sites dominated by Xiphocaris and Atya (Atydidae). Total insect densities were low and insect shredders were rare, but shrimp densities approached 30 individuals per square meter. At lower elevations, the role of atyids in leaf processing was suppressed by the activity of predatory Macrobrachium shrimps (Palaemonidae). In lowland Costa Rica, Rosemond et al. (1998) found that omnivorous fish and shrimps caused loss of weight from leaf packs although the cause (feeding and/or physical disruption) was not identified. In a Kenyan stream, freshwater crabs comminuted large amounts of leaf litter within the space of a few days (Moss, 2007). While our understanding of the role and importance of shredders in tropical streams is evolving, the functional replacement of insects and small crustaceans by larger decapod shredders (shrimps and crabs) appears to be a general feature in the tropics (Dudgeon, 1999; Dobson et al., 2002; Wantzen and Wagner, 2006), with decapods (especially atyid shrimps) occupying the niches filled by amphipod and isopod detritivores in north temperate. More research on the feeding activities of these creatures is needed, since recent work indicates shrimp contributions to litter processing and fragmentation do not reflect the significance of this energy source to their diet or secondary production (Yam and Dudgeon, 2005).

\section{METHODOLOGICAL CONSTRAINTS ON DECOMPOSITION STUDIES}

There are substantial interspecific differences in the physical and chemical composition of leaves (see Section III). Even within the same species, the toughness, form, and chemical composition varies in response to edaphic and climatic conditions, and can depend also on the degree of leaf senescence and extent of herbivory and pathogen attack. Because of the species richness of tropical trees and the fact that synchronized abscission periods are often lacking, many researchers in the tropics have used green leaves, or dried samples of fresh leaves that were sampled prior to abscission, as a means of investigating litter decomposition. Green leaves have a different physical and chemical structure than senescent, naturally abscised leaves, and this will affect their decomposition and palatability to detritivores. Studies of a feeding by a chironomid (Stenochironomus: Diptera) leaf miner in a Neotropical stream has shown that green leaves both from temperate and tropical tree species were consumed rapidly (Wantzen and Wagner, 2006), whereas naturally fallen leaf litter showed extremely slow decomposition (K. M. Wantzen et al., unpublished observations).

The tendency to use fresh leaves in decomposition studies, and the confounding effects of seasonal flow patterns and poorly known life cycles of detritivores in tropical streams, hamper our ability to make latitudinal or regional comparisons of litter processing between latitudes or among regions. Indeed, even within a region or a single stream, there are marked species-specific differences between decomposition rates (see review by Abelho, 2001; Table IV). For instance, Dobson et al. (2003) found that rates of mass-specific loss varied as much as five times among leaves in a Kenyan stream, but these researchers and Mathooko et al. (2000a) found that leaves in most species had broken down almost entirely within 3-4 months. However, one species (Syzygium cordatum) with tough, well-defended leaves was estimated to persist for well over 2 years (Mathooko et al., 2000b).

Despite differences in methods used, some general trends emerge from the array of decomposition studies reviewed by Abelho (2001) and the more recent tropical literature (Table IV). Leaves of rapidly growing tree species from nutrient-rich environments (e.g. whitewater floodplains; Furch and Junk, 1997; Rueda-Delgado et al., 2006) or fertile volcanic soils (Benstead, 1996) have faster decomposition rates than leaves of trees from nutrient-poor rainforest areas (Rueda-Delgado et al., 2006); leaves from peat swamp trees have the slowest decomposition rates (K. M. Wantzen and C. M. Yule, unpublished observations). 
The methods used in decomposition studies in the tropics and elsewhere vary greatly, and have been critically reviewed by Boulton and Boon (1991) and, more recently, by Graça et al. (2005). Decisions about study methodology are important because they affect estimates of decomposition rate regardless of site and species. Season also plays an influential role; RuedaDelgado et al. (2006) found highly significant differences in leaf decomposition rates between the backflooded phase and the flashy-discharge phase of Arenosa Stream in Colombia (Table IV; see also Section F.). Comparability of future studies of leaf decomposition will depend on the use of a standard methodology across sites/countries as seen, for example, in the WW-DECOEX project (Wantzen and Wagner, 2006). Key components of this protocol include the use of 5$10 \mathrm{~g}$ recently shed air-dried litter inside mesh bags (mesh size $5 \mathrm{~mm}$ ) with sufficient being placed at the start of the study to allow collection of at least five replicates on each sampling interval. Bag retrieval should take place after 1, 7, 14, 28, and 56 days, and after 6 and 12 months (if leaves persist for that long), with decomposition (i.e. weight loss of leaves) measured as ash-free dry matter (AFDM). When large benthic omnivores are present, additional leaf packs (i.e. leaves tethered with thread) should be deployed so that potential shredders can gain access to the litter. The use of electric fences to exclude larger consumers (e.g. Rosemond et al., 1998; March et al., 2001) may give further insights into their role in litter processing.

\section{AUTOCHTHONOUS PLANT LITTER}

A conventional view of stream ecology is that shading by terrestrial vegetation, especially at low-order sites, limits autochthonous primary production so that stream organic matter budgets depend mainly on allochthonous inputs (Vannote et al., 1980). Inevitably, this simple model does not apply in all circumstances, even in temperate latitudes (e.g. Franken et al., 2005). In Neotropical savannas, stretches of closed forest canopy alternate with sections of scattered gallery forest and grassland (Wantzen, 2003). Shallow soils, recurrent fires and water-logged soils in hyperseasonal savannas reduce the growth of tall trees (Oliveira-Filho et al., 1989) and, in such circumstance, in-stream primary production may be high. Human clearance of forest for the development of pastures and agriculture also facilitates autochthonous production (Martinelli et al., 1999; Mathooko and Kariuki, 2000). Even in closed-canopy tropical sites, aquatic macrophyte growth can be considerable if the current is not excessive (e.g. Furch and Junk, 1980). The fate of this autochthonous plant material after death is not clear and requires study. However, isotopic studies of riparian and emergent grasses in tropical Australia and Brazil indicate that, despite high biomass, their contributions to in-stream organic carbon budgets are limited (Bunn et al., 1997; Martinelli et al., 1999; for details, see Chapter 2, Sections II-B and III-A).

\section{CONCLUSIONS}

Although the general features of organic matter processing in northern-temperate and tropical streams are similar, some differences between them are nonetheless evident (for further consideration of latitudinal differences, see Chapter 9). Leaf litter input into tropical streams generally comprises a greater range of species, and the timing of the input ranges from completely asynchronous in the wet tropics to more-or-less synchronous in savanna climates. Higher ambient temperatures and the lack of winter freezing remove temperature constraints on decomposition rates, and may have the consequence that litter quality has a more influential role on organic matter dynamics in the tropics than in temperate streams. Warmer temperatures directly 
affect metazoans (e.g. Sweeney, 1984), and may alter the proportionate contributions of metazoans and microbes to organic matter processing (Irons et al., 1994) as well as influencing the relative importance of fungi and bacteria (Graça, 1993).

While seasonality in temperate streams is determined by temperature and day length, tropical streams are either aseasonal (e.g. Yule and Pearson, 1996) or seasonality tends to be linked with flow fluctuations (e.g. Dudgeon, 2000; Wantzen and Junk, 2000; Junk and Wantzen, 2004). Life cycles of detritivores in temperate streams appear synchronized with leaf availability (e.g. Cummins et al., 1989) and, in that sense, consumers seem to be adapted to make efficient use of litter inputs (see Vannote et al., 1980). In seasonal tropical streams, there is little evidence of adaptation of detritivores to make use of dry-season accumulations of leaves (Wantzen and Wagner, 2006), and wet-season spates may flush out litter before it is processed by consumers. Aseasonal tropical streams are particularly 'flashy', and this means that leaves may not be retained in streams long enough for decomposition to be completed. The range of plant secondary and structural compounds in tropical leaves probably limits the importance of shredders in leaf breakdown, and there is evidence that a significant proportion of the litter input may enter the stream as fine particles rather than intact leaves (e.g. Yule and Pearson, 1996). Therefore, it seems possible that collectors and filter feeders that consume physically and microbially degraded leaves play a crucial role in organic matter processing in tropical streams than shredders.

Our ability to generalize about differences between organic matter processing between tropical and temperate streams, and the organisms involved in such processing, is constrained by the fact that we still know little of the diversity of aquatic invertebrates in tropical streams (Vinson and Hawkins, 1998; Wantzen and Junk, 2000). As in temperate latitudes, this biota is likely to be influenced strongly by diversity of the surrounding vegetation, and thus it seems an appropriate precautionary principle to maintain riparian zones as a primary goal for conservation of biodiversity and ecosystem functioning in tropical streams (Dudgeon, 2000; Pringle, 2001; Wantzen et al., 2006; see also Chapter 10). A further constraint on generalization is the extent of biogeographic and regional variation within tropical and temperate latitudes; not all 'topical' streams are alike or represent a single type, and neither are all 'temperate streams' similar to each other; both represent a range of ecosystem types. The data that we have presented here indicate that while the number of tropical streams studied may be too small to permit robust generalizations, they are sufficient to indicate the extent of regional differences within the tropics. Further research is needed to uncover the extent of these differences, their importance, and the factors that underlie them.

Research priorities that need attention include measures of the amounts and condition of litter entering streams, in particular the relative importance of intact versus fragmented, partially decomposed leaves, and possible facilitation of aquatic breakdown by initial processing on land. This needs to be accompanied by estimates of litter retention in streams, especially large accumulations of detritus, and the responses of this material (and associated organisms) to seasonal and aseasonal flow pulses and flood events. Knowledge of the importance of inputs of other allochthonous energy sources aside from leaves (wood, fruit, flowers, frass, carcasses of insects and other animals) will also be required for elaboration of stream energy budgets. Better understanding of the role of plant defensive and structural compounds in litter breakdown are also needed, as this will influence how much litter is processed in situ or exported downstream in a relatively undecomposed or refractory condition. In addition, the relative importance of fungi and bacteria, and the way in which they interact to influence organic matter processing is poorly understood, and the relationship between microbial and faunal activities - especially the role of shredders - is still unclear. While tropical shredders appear to be less abundant and consequently less important in organic matter processing than their temperate counterparts, detailed purpose-designed studies will be needed to confirm this premise. 


\section{REFERENCES}

Abelho, M. (2001). From litterfall to breakdown in streams: a review. The Scientific World 1, 656-680.

Aerts, R. (1997). Climate, leaf litter chemistry and leaf litter decomposition in terrestrial ecosystems: a triangular relationship. Oikos 79, 439-449.

Ardón, M., Stallcup, L. A., and Pringle, C. M. (2006). Does leaf quality stimulate the stimulation of leaf breakdown by phosphorus in Neotropical streams? Freshwater Biology 51, 618-633.

Bärlocher, F., and Kendrick, B. (1974). Dynamics of the fungal population on leaves in a stream. Journal of Ecology 63, 761-791.

Barthlott, W., Lauer, W., and Placke, A. (1996). Global distribution of species diversity in vascular plants: towards world map of phytodiversity. Erdkunde 50, 317-327.

Benstead, J. P. (1996). Macroinvertebrates and the processing of leaf litter in a tropical stream. Biotropica 28, 367-375.

Boulton, A. J. (1991). Eucalypt leaf decomposition in an intermittent-stream in South-Eastern Australia. Hydrobiologia 211, 123-136.

Boulton, A. J., and Boon, P. I. (1991). A review of methodology used to measure leaf litter decomposition in lotic environments: time to turn over an old leaf? Australian Journal of Marine and Freshwater Research 42, 1-43.

Bowen, S. H. (1983). Detritivory in Neotropical fish communities. Environmental Biology of Fishes 9, 137-144.

Bray, J. R., and Gorham, E. (1964). Litter production in the forests of the world. Advances in Ecological Research 2, 101-157.

Bunn, S. E. (1988). Processing of leaf litter in two northern jarrah forest streams, Western Australia: II. The role of macroinvertebrates and the influence of soluble polyphenols and inorganic sediment. Hydrobiologia 162, 211-223.

Bunn, S. E., Davies, P. M., and Kellaway, D. M. (1997). Contributions of sugar cane and invasive pasture grass to the aquatic food web of a tropical lowland stream. Marine and Freshwater Research 48, 173-179.

Butin, H. (1995). “Tree Diseases and Disorders: Causes, Biology, and Control in Forest and Amenity Trees." Oxford University Press, Oxford.

Capello, S., Marchese, M. R., and Ezcurra de Drago, I. (2004). Descomposición de hojas de Salix humboldtiana y colonización por invertebrados en la llanura de inundación del río Paraná Medio. Amazoniana 18, 125-144.

Chan, E. K. W., and Dudgeon, D. (2006). Riparian vegetation affects the food supply of stream fish in Hong Kong. In Jim, C. Y. and Corlett, R.T. (eds.) "Sustainable Management of Protected Areas for Future Generations" pp. 219-231. World Conservation Union (IUCN) and World Commission on Protected Area (WPCA), Gland, Switzerland.

Cheshire, K., Boyero, L., and Pearson, R. G. (2005). Food webs in tropical Australian streams: shredders are not scarce. Freshwater Biology 50, 748-769.

Coley, P. D. (1988). Effects of plant growth rate and leaf lifetime on the amount and type of anti-herbivore defense. Oecologia 74, 531-536.

Coley, P. D., and Barone, J. A. (1996). Herbivory and plant defenses in tropical forests. Annual Review of Ecology and Systematics 27, 305-335.

Covich, A. P. (1988). Geographical and historical comparisons of Neotropical streams: biotic diversity and detrital processing in highly variable habitats. Journal of the North American Benthological Society 7, 61-386.

Covich, A. P., and McDowell, W. H. (1996). The stream community. In Reagan, D. P. and Waide, R. B. (eds.) "The Food Web of a Tropical Rain Forest.” pp. 433-459. University of Chicago Press, Chicago, IL.

Crowl, T. A., McDowell, W. H., Covich, A. P., and Johnson, S. L. (2001). Freshwater shrimp effects on detrital processing and nutrients in a tropical headwater stream. Ecology 82, 775-783.

Cummins, K. W., Wilzbach, M. A., Gates, D. M., Perry, J. B., and Taliaferro, W. B. (1989). Shredders and riparian vegetation. Bioscience 39, 24-30.

Diez, J. R., Larrañaga, S., Elosgi, A., and Pozo, J. (2000). Effect of removal of wood on streambed quality and retention of organic matter. Journal of the North American Benthological Society 19, 621-632.

Dobson, M., Magana, A., Mathooko, J. M., and Ndegwa, F. K. (2002). Detritivores in Kenyan highland streams: more evidence for the paucity of shredders in the tropics? Freshwater Biology 47, 909-919.

Dobson, M., Mathooko, J. M., Ndegwa, F. K., and M'Erimba, C. M. (2003). Leaf litter processing in a Kenyan highland stream, the Njoro River. Hydrobiologia 519, 207-210.

Dudgeon, D. (1992). "Patterns and Processes in Stream Ecology. A Synoptic Review of Hong Kong Running Waters." (Die Binnengewässer, Vol. 29). 147 pp. Schweizerbartsche Buchhandlung, Stuttgart.

Dudgeon, D. (1994). The influence of riparian vegetation on macroinvertebrate community structure and functional organization in six New Guinea streams. Hydrobiologia 294, 65-85.

Dudgeon, D. (1999). “Tropical Asian Streams: Zoobenthos, Ecology and Conservation.” 830 pp. Hong Kong University Press, Hong Kong.

Dudgeon, D. (2000). The ecology of tropical Asian rivers and streams in relation to biodiversity conservation. Annual Review of Ecology and Systematics 31, 239-263. 
Dudgeon, D., and Bretschko, G. (1996). Allochthonous inputs in land-water interactions in seasonal streams: tropical Asia and temperate Europa. In Schiemer, F. and Boland, K. T. (eds.) "Perspectives in Tropical Limnology." pp. 161-179. SPB Academic Publishing, Amsterdam.

Dudgeon, D., and Wu, K. K. Y. (1999). Leaf litter in a tropical stream: food or substrate for macroinvertebrates? Archiv für Hydrobiologie 146, 65-82.

Duffey, D., and Stout, M. J. (1996). Antinutritive and toxic components of plant defensive against insects. Archives of Insect Biochemistry and Physiology 32, 3-37.

Enríquez, S., Duarte, C. M., and Sand-Jensen, K. (1993). Patterns in decomposition rates among photosynthetic organisms: the importance of detritus C : N : P content. Oecologia 94, 457-471.

Fazi, S., and Rossi, L. (2000). Effects of macro-detritivores density on deaf detritus processing rate: a macrocosm experiment. Hydrobiologia 435, 127-134.

Fisher, S. G. (1983). Succession in streams. In Barnes, J. R. and Minshall, G. W. (eds.) "Stream Ecology: Application and Testing of General Ecological Theory.” pp. 7-27. Plenum Press, New York.

Fittkau, E. J. (1982). Struktur, Funktion und Diversität zentralamazonischer Ökosysteme. Archiv für Hydrobiologie 95, 29-45.

France, R. L., Culbert, H., Freeborough, C., and Peters, R. H. (1997). Leaching and early mass loss of boreal leaves and wood in oligotrophic water. Hydrobiologia 345, 209-214.

Franken, W. (1979). Untersuchungen im Einzugsgebiet des zentralamazonischen Urwaldbaches "Barro Branco" auf der "terra firme": I. Abflußverhalten des Baches. Amazoniana 6, 459-466.

Franken, R. J. M., Peeters, E. T. H. M., Gardeniers, J. J. P., Beijer, J. A. J., and Scheffer, M. (2005). Growth of shredders on leaf litter biofilms: the effect of light intensity. Freshwater Biology 50, 459-466.

Furch, K., and Junk, W. J. (1980). Water chemistry and macrophytes of crecks and rivers in Southern Amazonia and the Central Brazilian Shield. In: Furtado, J. I. (ed.): “Tropical Ecology and Development”, pp. 771-796. The International Society of Tropical Ecology, Kuala Lumpur.

Furch, K., and Junk, W. J. (1997). The chemical composition, food value and decomposition of herbaceous plants and leaf litter of the floodplain forest. In Junk, W. J. (ed.) "The Central Amazonian Floodplain: Ecology of a Pulsing System.” pp. 187-205. Springer, Berlin.

Garg, R. K., and Vyas, L. N. (1975). Litter production in deciduous forest Near Udaipur (South Rajasthan), India. In Golley, F. B. and Medina, E. (eds.) "Tropical Ecological Systems. Trends in Terrestrial and Aquatic Research." pp. 131-135. Springer, New York.

Gessner, M. O. (1991). Differences in processing dynamics of fresh and dried leaf litter in a stream ecosystem. Freshwater Biology 26, 387-398.

Gessner, M. O., and Chauvet, E. (1994). Importance of stream microfungi in controlling breakdown rates of leaf litter. Ecology 75, 1807-1817.

Gessner, M. O., Suberkropp, K., and Chauvet, E. (1997). Decomposition of plant litter by fungi in marine and freshwater ecosystems. In Wicklow, W. and Söderström, J. (eds.) “The Mycota IV - Environmental and Microbial Relationships.” pp. 303-321. Springer, Berlin.

Gessner, M. O., Chauvet, E. and Dobson, M. (1999). A perspective on leaf litter breakdown in streams. Oikos $85,377-384$.

Goulding, M., Carvalho, M. L., and Ferreira, E. G. (1988). "Rio Negro, South America - Rich Life in Poor Water: Amazonian Diversity and Foodchain Ecology as Seen Through Fish Communities.” 200 pp. SBP Publishing, The Hague.

Graça, M. A. S. (1993). Patterns and processes in detritus-based stream systems. Limnologica 23, 107-114.

Graça, M. A. S., Bärlocher, F., and Gessner, M. O. (2005). “Methods to Study Litter Decomposition - a Practical Guide." Springer, Berlin.

Haase, R. (1999). Litterfall and nutrient return in seasonally flooded and non-flooded forest of the Pantanal, Mato Grosso, Brazil. Forest Ecology and Management 117, 129-147.

Hartshorn, G. S. (1983). Plants. In Janzen, D. H. (ed.) “Costa Rican Natural History.” pp. 118-183. University of Chicago Press, Chicago, IL.

Heard, S. B., and Richardson, J. S. (1995). Shredder-collector facilitation in stream detrital food webs: is there enough evidence? Oikos 72, 359-366.

Henderson, P. A., and Walker, I. (1986). On the leaf litter community of the Amazonian blackwater stream Tarumzinho. Journal of Tropical Ecology 2, 1-17.

Herbst, G. N. (1980). Effects of burial on food value and consumption of leaf detritus by aquatic invertebrates in a lowland forest stream. Oikos 35, 411-424.

Hynes, H. B. N. (1970). “The Ecology of Running Waters.” University of Toronto Press, Toronto.

Irons, J. G., Oswood, M. W., Stout, R. J., and Pringle, C. M. (1994). Latitudinal patterns in leaf litter breakdown: is temperature really important? Freshwater Biology 32, 401-411.

Janzen, D. H. (1974). Tropical blackwater rivers, animals, and mast fruiting by the Dipterocarpaceae. Biotropica 6, 69-103. 
Junk, W. J., and Robertson, B. A. (1997). Aquatic invertebrates. In Junk, W. J. (ed.) "The Central Amazonian Floodplain: Ecology of a Pulsing System.” pp. 279-298. Springer, Berlin.

Junk, W. J., and Wantzen, K. M. (2004). The flood pulse concept: new aspects, approaches, and applications - an update. In Welcomme, R. and Petr, T. (eds.) "Proceedings of the 2nd Large River Symposium (LARS), Pnom Penh, Cambodia.” pp. 117-149. RAP Publication 2004/16. Food and Agriculture Organization and Mekong River Commission. FAO Regional Office for Asia and the Pacific, Bangkok.

Kaushik, N. K., and Hynes, H. B. N. (1971). The fate of dead leaves that fall into streams. Archiv für Hydrobiologie $68,465-515$.

Kiew, R. (1998). Species richness and endemism. In Soepadmo, E. (ed.) “The Encyclopedia of Malaysia: Plants.” pp. 14-15. Archipelago Press, Singapore.

Knöppel, H.-A. (1970). Food of Central Amazonian fishes. Contribution to the nutrient-ecology of amazonian rainforest-streams. Amazoniana 2, 257-352.

Larned, S. T. (2000). Dynamics of coarse riparian detritus in a Hawaiian stream ecosystem: a comparison of drought and post-drought conditions. Journal of the North American Benthological Society 19, 215-234.

Larned, S. T., Chong, C. T., and Punewai, N. (2001). Detrital fruit processing in a Hawaiian stream ecosystem. Biotropica 33, 241-248.

Lodge, D. J., and Asbury, C. E. (1988). Basidiomycetes reduce export of organic matter from forest slopes. Mycologia $80,888-890$.

March, J. G., Benstead, J. P., Pringle, C. M., and Ruebel, M. W. (2001). Linking shrimp assemblages with rates of detrital processing along an elevational gradient in a tropical stream. Canadian Journal of Fisheries and Aquatic Sciences 58, 470-478.

Martinelli, L. A., Ballester, M. V., Krusche, A. V., Victória, R. L., de Camargo, P. B., Bernardes, M., and Ometto, J. P. H. B. (1999). Landcover changes and $\delta^{13} \mathrm{C}$ composition of riverine particulate organic matter in the Piracicaba River basin (southeast region of Brazil). Limnology and Oceanography 44, 1826-1833.

Marvanova, L. (1997). Freshwater hyphomycetes: a survey with remarks on tropical taxa. In Janardhanan, K.K., Rajendran, K. C., Natarajan, M. and Hawksworth, D. L. (eds.) “Tropical Mycology.” pp. 169-226. Science Publishers, Enfield, $\mathrm{NH}$

Mathooko, J. M. (1995). The retention of plant coarse particulate organic matter (CPOM) at the surface of the wet-store and dry-store zones of the Njoro River, Kenya. African Journal of Ecology 33, 159.

Mathooko, J. M., and Kariuki, S. T. (2000). Disturbances and species distribution of the riparian vegetation of a Rift Valley stream. African Journal of Ecology 38, 123-129.

Mathooko, J. M., and Mavuti, K. M. (1992). Composition and seasonality of benthic invertebrates, and drift in the Naro Moru River, Kenya. Hydrobiologia 232, 47-56.

Mathooko, J. M., M’Erimba, C. M. and Leichtfried, M. (2000a). Decomposition of leaf litter of Dombeya goetzenii in the Njoro River, Kenya. Hydrobiologia 418, 147-152.

Mathooko, J. M., Magana, A. M., and Nyang'au, I. M. (2000b). Decomposition of Syzygium cordatum in a Rift Valley stream ecosystem. African Journal of Ecology 38, 365-368.

Mathooko, J. M., Morara, G. O., and Leichtfried, M. (2001). Leaf litter transport and retention in a tropical Rift Valley stream: an experimental approach. Hydrobiologia 443, 9-18.

Mathuriau, C., and Chauvet, E. (2002). Breakdown of leaf litter in a Neotropical stream. Journal of the North American Benthological Society 2, 384-396.

Mayack, D. T., Thorp, J. H., and Cothran, M. (1989). Effects of burial and floodplain retention on stream processing of allochthonous litter. Oikos 54, 378-388.

McClain, M. E., and Richey, J. E. (1996). Regional-scale linkages of terrestrial and lotic ecosystems in the Amazon basin: a conceptual model for organic matter. Algological Studies 113, 111-125.

Melillo, J. M., Naiman, R. J., Aber, J. D., and Eshleman, K. N. (1983). The influence of substrate quality and steam size on wood decomposition dynamics. Oecologia 58, 281-285.

Metzler, G. M., and Smock, L. A. (1990). Storage and dynamics of subsurface detritus in a sand-bottomed stream. Canadian Journal of Fisheries and Aquatic Sciences 47, 588-594.

Morara, G. O., Mathooko, J. M., and Leichtfried, M. (2003). Natural leaf litter transport and retention in a secondorder tropical stream: the Njoro River, Kenya. African Journal of Ecology 41, 277-279.

Moss, B. (2007). Rapid shredding of leaves by crabs in a tropical African stream. Verhandlungen Internationale Vereinigung für Limnologie 29, in press.

Nakano, S., Miyasaka, H., and Naotoshi, K. (1999). Terrestrial-aquatic linkages: riparian arthropod inputs alter trophic cascades in a stream food web. Ecology 80, 2435-2441.

Ogawa, H. (1978). Litter production and carbon cycling in Pasoh Forest. Malaysian Nature Journal 30, 367-373.

Oliveira-Filho, A. T., Shepherd, J. G., Martins, F. M., and Stubblebine, W. H. (1989). Environmental factors affecting physiognomic and floristic variation in an area of Cerrado in central Brazil. Journal of Tropical Ecology $5,413-431$.

Ostrofsky, M. L. (1997). Relationship between chemical characteristics of autumn-shed leaves and aquatic processing rates. Journal of the North American Benthological Society 16, 750-759. 
Parnrong, S., Buapetch, K., and Buathong, M. (2002). Leaf decomposition rates in three tropical streams of southern Thailand: the influence of land use. Verhandlungen Internationale Vereinigung für Limnologie 28, 475-479.

Pearson, R. G., Tobin, R. K., Smith, R. E. W., and Benson, L. J. (1989). Standing crop and processing of rainforest litter in a tropical Australian stream. Archiv für Hydrobiologie 115, 481-498.

Pringle, C. M. (2001). River conservation in tropical versus temperate latitudes. In Boon, P. J., Davies, B. R. and Petts, G. E. (eds.) “Global Perspectives on River Conservation: Science, Policy and Practice.” pp. 373-383. John Wiley \& Sons Ltd., Chichester.

Pringle, C. M., Hemphill, N., McDowell, W. H., Bednarek, A., and March, J. G. (1999). Linking species and ecosystems: different biotic assemblages cause interstream differences in organic matter. Ecology 80, 1860-1872.

Raviraja, N. S., Sridhar, K. R., and Bärlocher, F. (1998). Breakdown of Ficus and Eucalyptus leaves in an organically polluted river in India: fungal diversity and ecological functions. Freshwater Biology 39, 537-545.

Rosemond, A. D., Pringle, C. M., and Ramírez, A. (1998). Macroconsumer effects on insect detritivores and detritus processing in a tropical stream. Freshwater Biology 39, 515-523.

Rosemond, A. D., Pringle, C. M., Ramírez, A., Paul, M. J., and Meyer, J. (2002). Landscape variation in phosphorus concentration and effect on detritus-based tropical streams. Limnology and Oceanography 47, 278-289.

Rounick, J. S., and Winterbourn, M. J. (1983). Leaf processing in two contrasting beech forest streams: effects of physical and biotic factors on litter breakdown. Archiv für Hydrobiologie 96, 448-474.

Rueda-Delgado, G., Wantzen, K. M., and Beltrán, M. (2006). Leaf litter decomposition in an Amazonian floodplain stream: impacts of seasonal hydrological changes. Journal of the North American Benthological Society 25, 231-247.

Sakai, S. (2002). General flowering in lowland mixed dipterocarp forests of South-east Asia. Biological Journal of the Linnean Society 75, 233-247.

Schwarz, A. E., and Schwoerbel, J. (1997). The aquatic processing of sclerophyllous and malacophyllous leaves on a Mediterranean island (Corsica): spatial and temporal pattern. Annales de Limnologie 33, 107-119.

Souza, M. L., and Moulton, T. P. (2005). The effects of shrimps on benthic material in a Brazilian island stream. Freshwater Biology 50, 592-602.

Stallcup, L. A., Ardón, M., and Pringle, C. M. (2006). Effects of P- and N-enrichment on leaf breakdown in detritusbased tropical streams. Freshwater Biology 51, 1515-1526.

Stout, R. J. (1989). Effects of condensed tannins on leaf processing in mid-latitude and tropical streams: a theoretical approach. Canadian Journal of Fisheries and Aquatic Sciences 46, 1097-1106.

Strauss, E. A., and Lamberti, G. A. (2002). Effect of dissolved organic carbon quality on microbial decomposition and nitrification rates in stream sediments. Freshwater Biology 47, 65-74.

Suberkropp, K. (1998). Microorganisms and organic matter decomposition. In Naiman, R. J. and Bilby, R. E. (eds.) "River Ecology and Management. Lessons from the Pacific Coastal Region." pp. 120-143. Springer, New York.

Sweeney, B. W. (1984). Factors influencing life history patterns of aquatic insects. In Resh, V. H. and Rosenberg, D. M. (eds.) "Ecology of Aquatic Insects.” pp. 56-100. Praeger Scientific Publishers, New York.

Vannote, R. L., Minshall, G. W., Cummins, K. W., Sedell, K. W., and Cushing, C. E. (1980). The River Continuum Concept. Canadian Journal of Fisheries and Aquatic Sciences 37, 130-137.

Vinson, M. R. and Hawkins, C. P. (1998). Biodiversity of stream insects: variation at local, basin, and regional scales. Annual Review of Entomology 43, 271-293.

Walker, I. (1986). Experiments on colonization of small water bodies by Culicidae and Chironomidae as a function of decomposing plant substrates and implications for natural Amazonian Ecosystems. Amazoniana 10, 113-125.

Walker, I. (1987). The biology of streams as a part of Amazonian forest ecology. Experientia 43, 279-287.

Walker, I. (1995). Amazonian streams and small rivers. In Tundisi, J. G., Bicudo, C. E. M. and Matsamura-Tundisi, T. (eds.) "Limnology in Brazil.” pp. 167-194. Brazilian Academy of Sciences, Rio de Janeiro.

Wantzen, K. M. (2003). Cerrado Streams - characteristics of a threatened freshwater ecosystem type on the tertiary shields of South America. Amazoniana 17, 485-502.

Wantzen, K. M. (2006). Physical pollution: effects of gully erosion in a tropical clear-water stream. Aquatic Conservation $16,733-749$.

Wantzen, K. M., and Junk, W. J. (2000). The importance of stream-wetland-systems for biodiversity: a tropical perspective. In Gopal, B., Junk, W. J. and Davies, J. A. (eds.) "Biodiversity in Wetlands: Assessment, Function and Conservation.” pp. 11-34. Backhuys, Leiden, The Netherlands.

Wantzen, K. M., and Junk, W. J. (2006). Aquatic-terrestrial linkages from streams to rivers: biotic hot spots and hot moments. Archiv für Hydrobiologie/Supplement 158, 595-611.

Wantzen, K. M., and Junk, W. J. (in press). Riparian wetlands. In Ronan, B. (ed.) “Encyclopedia of Ecology.” Elsevier, Amsterdam.

Wantzen, K. M., and Wagner, R. (2006). Detritus processing by shredders: a tropical-temperate comparison. Journal of the North American Benthological Society 25, 214-230.

Wantzen, K. M., Wagner, R., Suetfeld, R., and Junk, W. J. (2002). How do plant-herbivore interactions of trees influence coarse detritus processing by shredders in aquatic ecosystems of different latitudes? Verhandlungen Internationale Vereinigung für Limnologie 28, 815-821. 
Wantzen, K. M., Da Rosa, F. R., Neves, C. O., and Nunes da Cunha, C. (2005a). Leaf litter addition experiments in riparian ponds with different connectivity to a Cerrado Stream in Mato Grosso, Brazil.Amazoniana 18, 387-396.

Wantzen, K. M., Drago, E., and da Silva, C. J. (2005b). Aquatic habitats of the Upper Paraguay River-Floodplain-System and parts of the Pantanal (Brazil). Ecohydrology and Hydrobiology 21, 1-15.

Wantzen, K. M., Sá, M. F. P., Siqueira, A., and Nunes da Cunha, C. (2006). Conservation scheme for forest-streamecosystems of the Brazilian Cerrado and similar biomes in the seasonal tropics. Aquatic Conservation 16, 713-732.

Webster, J. R., and Benfield, E. F. (1986). Vascular plant breakdown in freshwater ecosystems. Annual Review of Ecology and Systematics 17, 567-594.

Wittmann, F., Junk, W. J., and Piedade, M. T. F. (2004). The várzea forests in Amazonia: flooding and the highly dynamic geomorphology interact with natural forest succession. Forest Ecology and Management 196, 199-212.

Wootton, J. T., and Oemke, M. P. (1992). Latitudinal differences in fish community trophic structure, and the role of fish herbivory in a Costa Rican stream. Environmental Biology of Fishes 35, 311-319.

Worbes, M., Klinge, H., Revilla, J. D., and Martius, C. (1992). On the dynamics, floristic subdivision and geographical distribution of várzea forests in Central Amazonia. Journal of Vegetation Sciences 3, 553-564.

Wright, M. S., and Covich, A. P. (2005). Relative importance of Bacteria and Fungi in a Tropical Headwater Stream: Leaf decomposition and invertebrate feeding preference. Microbial Ecology 49: 536-546.

Yam, S. W. R., and Dudgeon, D. (2005). Stable isotope investigation of food use by Caridina spp. (Decapoda: Atyidae) in Hong Kong streams. Journal of the North American Benthological Society 24, 68-81.

Yule, C. M. (1996). Trophic relationships and food webs of the benthic invertebrate fauna of two aseasonal tropical streams on Bougainville Island, Papua New Guinea. Journal of Tropical Ecology 12, 517-534.

Yule, C. M., and Pearson, R. G. (1996). Aseasonality of benthic invertebrates in a tropical stream on Bougainville Island, Papua New Guinea. Archiv für Hydrobiologie 137, 5-117. 